Hasil Penelitian

\title{
STRATEGI PENGEMBANGAN KEgIATAN KEAgAMAAN ANAK USIA DINI DI TK haRApAN IBU TANAH mas BANYUASIN
}

\author{
$\mathcal{O N y i m a s} \mathcal{O}$ Nurrohma
}

\author{
Program Pascasarjana \\ Universitas Islam Negeri Raden Fatah Palembang \\ E-mail: nyimas_uin@radenfatah.ac
}

\begin{abstract}
This study found that first, the kindergarten strategy in developing the early childhood religious activities in Harapan Ibu Tanah Banyuasin kindergarten was pursued by establishing the development of the religious activities of the AUD that wanted to be internalized, establishing the form of its assessment, planning daily habituation along with its religious activity programs, applying Development of religious activities, awaken to all teachers of important roles and responsibilities in achieving the goal of developing religious activities in early childhood, as well as cooperating with the guardian of students in the development of early childhood religious activities in the kindergarten. Then the second discovery, finding the learning method used that is using exemplary methods, habituation, attention and supervision, methods of advice, game methods and story methods. Then the third finding, The supporting factor in developing the early childhood religious activities in kindergarten Harapan Ibu Tanah Mas Banyuasin is the awareness of the classroom teachers on the importance of the development of early childhood religious activities, the presence of good facilities and infrastructure, the establishment of harmonious cooperation between The school and parents in terms of developing the early childhood religious activities, the attention of both teachers and parents, the happiness of learners as well as inhibiting in developing the early childhood religious activities of the absence of awareness of the teacher on the importance of the development of religious activities, Lack of facilities and infrastructure, no good cooperation between parents and teachers, the lack of attention of parents and teachers in terms of religious activities of early childhood and the last absence of the happiness of learners in following the religious activities that take place.
\end{abstract}

Keywords: Strategy, development, activities, religious, early childhood

\begin{abstract}
Abstrak
Penelitian ini menemukan bahwa pertama, strategi pihak TK dalam mengembangkan kegiatan keagamaan anak usia dini di TK Harapan Ibu Tanah Banyuasin ditempuh dengan menetapkan pengembangan kegiatan keagamaan AUD yang hendak diinternalisasikan, menetapkan bentuk penilaiannya, merencanakan pembiasaan sehari-hari beserta program-program kegiatan keagamaannya, menerapkan pengembangan kegiatan keagamaannya, menyadarkan pada semua guru akan peran penting dan tanggung jawab dalam keberhasilan mencapai tujuan pengembangan kegiatan keagamaan pada anak usia dini, serta melakukan kerja sama dengan wali siswa dalam hal pengembangan kegiatan keagamaan anak usia dini di TK tersebut. Lalu penemuan yang kedua, menemukan metode pembelajaran yang dipakai yakni menggunakan metode keteladanan, pembiasaan, perhatian dan pengawasan, metode nasehat, metode permainan dan metode cerita. Kemudian temuan yang ketiga, Faktor pendukung dalam mengembangkan kegiatan keagamaan anak usia dini di TK Harapan Ibu Tanah Mas Banyuasin adalah adanya kesadaran dari guru kelas akan hal pentingnya pengembangan kegiatan keagamaan anak usia dini, adanya sarana dan prasarana yang baik, terjalinnya kerja sama yang harmonis antara pihak sekolah dan orang tua dalam hal mengembangkan kegiatan keagamaan anak usia dini, adanya perhatian baik dari guru dan orang tua, adanya kesemangatan dari peserta didik adapun penghambat dalam mengembangkan kegiatan keagamaan anak usia dini yaitu tidak adanya kesadaran dari guru akan hal penting pengembangan kegiatan keagamaan, kurangnya sarana dan prasarana, tidak terjalinnya kerjasama yang baik antara orang tua dan guru, kurangnya perhatian orang tua dan guru dalam hal kegiatan keagamaan anak usia dini dan terakhir tidak adanya kesemangatan dari peserta didik didalam mengikuti kegiatan keagamaan yang berlangsung.
\end{abstract}

Kata kunci: Strategi, pengembangan, kegiatan keagamaan, anak usia dini 


\section{Haril Penelitian}

Mencermati arus modern dewasa ini yang melanda seluruh masyarakat dunia, akibat pengaruh dari kemajuan teknologi dan informasi, tidak kecuali masyarakat muslim tentunya, diperlukan beberapa strategi untuk menyikapi kemajuankemajuan itu agar meminimalisir efek negatif dan memaksimalkan keuntungan positif sebagai instrumen untuk membekali anak didik menjadi pemimpin-pemimpin yang akan menguasai kecanggihan teknologi dan membekali dengan ketauhidan yang berakhir pada kualitas iman Islam. Dalam proses pengembangan kegiatan keagamaan anak usia dini, guru dan orang tua memiliki peran yang sangat utama dalam membantu pertumbuhan dan perkembangan anak. Di lingkungan keluarga anak mendapat pengalaman yang pertama dan utama. Dan di sekolah guru mempunyai peran yang sangat besar pengaruhnya dalam mengembangkan kegiatan keagamaan pada anak.

Taman kanak kanak adalah suatu tempat bermain untuk mengembangkan berbagai bidang seperti: 1) Bidang pengembangan nilai-nilai agama dan moral; 2) Bidang pengembangan karakter formal; 3) Bidang pengembangan fisik; 4) Bidang pengembangan kognitif; 5) Bidang pengembangan bahasa; dan 6) Bidang pengembangan sosial emosional (IGTK-PGRI, 2012: 25).

Hal ini sejalan dengan pendapat Khairon Rosyadi dalam bukunya pendidikan profetik menyebutkan bahwa tujuan khusus pendidikan agama Islam adalah " menumbuhkan dorongan agama dan akhlak" yang dapat dirincikan sebagai berikut (Rosyadi, 2009: 170): 1) Memperkenalkan kepada siswa akidah Islam, dasar akidah, asal usul ibadah, serta cara pelaksanaan ibadah dengan betul; 2) Menumbuhkan kesadaran yang betul pada diri siswa tentang prinsip akhlak yang mulia; 3) Menambah keimanan kepada Allah, malaikat, kitab, rasul, dan hari akhir; 4) Menumbuhkan rasa bangga terhadap sejarah dan kebudayaan Islam serta mengikuti jejak pahlawan mereka; 5) Menumbuhkan rasa rela, optimisme, kepercayaan dan tanggung jawab serta tolong menolong dalam kebajikan; dan 6) Mendidik naluri motivasi yang dapat membentangi mereka dalam segala persoalan yang ada.

Untuk mewujudkan tujuan diatas, maka peran pihak TK atau guru TK dalam mengembangan kegiatan keagamaan bisa berupa memberikan penjelasan dan praktek mengenai hal hal yang berkaitan dengan akidah Islam yakni seperti pelaksanaan manasik haji yang mereka praktekkan ketika bulan zulhijjah, yang mana pelaksanaan praktek ini merupakan ibadah yang termasuk rukun Islam yang kelima, sehingga dengan praktek yang telah dilakukan itu maka anak usia dini akan mengerti sedikit demi sedikit akan hal hal yang merupakan ibadah yang ada dalam rukun Islam dan merekapun bisa menyebutkan beberapa rukun Islam yang lainnya, dan dengan demikian jika mereka mampu menyebutkan rukun islam tersebut maka penilaian perkembangan anak didik dalam bidang pengembangan nilai-nilai agama sudah mereka peroleh.

Dalam strategi pengembangan kegiatan keagamaan pada anak atau pengembangan keimanan anak kepada sang khalik maka seorang guru yang cerdas akan mengkaitkan suatu kesalahan anak dengan memberikan keterangan berdasarkan agama yakni dari Al-qur'an dan hadist, dan tentunya sang guru akan menyampaikannya dengan sebaik mungkin atas perbuatan anak tersebut yang menurut agama tidak baik. Dan hal ini berhubungan dengan fungsi pendidikan nasional yakni: "mengembangkan kemampuan dan membentuk watak serta peradaban bangsa yang bermartabat dalam rangka mencerdaskan kehidupan bangsa, bertujuan untuk berkembangnya potensi peserta didik agar menjadi manusia yang beriman dan bertakwa kepada Tuhan yang maha Esa, berakhlak mulia, berilmu cakap, kreatif, mandiri, dan menjadi warga negara yang demokratis serta bertanggung jawab”.

Undang undang sistem pendidikan nasional menyatakan bahwa seorang guru benar benar harus berupaya untuk mengembangkan potensi peserta didik agar menjadi manusia beriman dengan sebaik mungkin, serta tentunya didalam mengajar atau mendidik anak khususnya anak yang berada ditaman kanak kanak haruslah mempunyai upaya atau strategi ampuh didalam menanamkan pendidikan agama Islam.

Selain itu guru khendaknya memiliki ilmu yang cakap, ia pun kreatif karena jika tak cakap menghadapi anak yang cengeng, yang bandel yang susah diatur maka tentunya sang guru akan mudah emosi, dan kekereatifan guru didalam mendidik anak taman kanak-kanakpun harus dimiliki agar 


\section{Hasil Penelition}

anak-anak senang dalam menerima pendidikan yang diajarkan oleh sang guru. Didalam mendidik anak Tk gurupun diharapkan memiliki kesabaran, apalagi ketika ingin mengembangkan keagamaan guru harus memiliki wawasan yang benar dan tak melenceng dari ajaran agama ketika akan menyampaikan ilmunya.

Dalam hal ini pengembangan kegiatan keagamaan dalam segi budi pekerti harus ditingkatkan seiring dengan kemajuan zaman dengan berbagai upaya, dan sang guru akan berupaya menerangkan bahwa sesungguhnya peserta didik itu merupakan makhluk bertuhan dimana jika bertuhan maka tentunya ada hal-hal yang perlu dilaksanakan untuk memenuhi kewajiban sebagai manusia dan strategi gurulah yang merupakan jalan untuk menyadarkaan akan hal-hal tersebut. Strategi-strategi tersebut perlu diteliti. Dengan demikian upaya-upaya selanjutnya untuk meningkatkan kualitas apa yang telah dicapai atau memperbaiki apa-apa yang masih kurang dalam rangka mengembangkan keagamaan pada anak usia dini.

Manusia adalah mahkluk dwitunggal yang terdiri atas jasmaniah dan ruhaniah, unsur rohaniahnya masih mencakup dua segi kejiwaan lagi, yaitu hakikat sebagai makhluk individu dan hakikat sebagai makhluk sosial. Dan satu hakikat lagi, yang membedakan manusia dengan makhluk lain ialah hakikat sebagai makhluk susila, makhluk berketuhanan, berdasarkan hakikat manusia itu, maka diperoleh berbagai aspek pendidikan dan salah satunya yaitu pendidikan budi pekerti. Budi pekerti atau akhlak adalah satu satunya aspek yang sangat fundamental dalam kehidupan. Baik bagi kehidupan sebagai orang orang maupun bagi kehidupan masyarakat. Tujuan dari pendidikan budi pekerti ialah mendidik anak agar dapat membedakan antara baik dan buruk, sopan dan tidak sopan sifat terpuji dan tercela, serta sebagainya (Idi, 2013: 89).

Sejalan dengan ajaran agama, yang berkenaan dengan akhlak dimana dalam ajaran agama telah menjelaskan bahwa betapa pentingnya mengembangkan keagamaan sedini mungkin sehingga jika dewasa mereka bisa mengaplikasikan ajaran ajaran kebaikan yang berdasarkan agama dengan sebaik baiknya. Pengamatan yang dilakukan peneliti dilakukan sejak tahun 2014 dimana terdapat anak yang enggan untuk membaca huruf hijaiyyah sehingga anak tersebut belum membiasakan dirinya untuk membaca iqro'. Pada dasarnya pengembangan kegiatan keagamaan dari segi membaca huruf hijaiyyah merupakan salah satu dari indikator program pembelajaran AUD dalam hal membiasakan diri beribadah.

Pengamatan juga dilakukan terhadap anak yang ada di TK Harapan Ibu dilakukan akhir bulan agustus 2015 dimana masih ada dari anak didik di TK tersebut membuang sampah sembarangan, pada dasarnya membuang sampah sembarangan merupakan perbuatan yang tak baik karena hal itu merupakan hal yang bertentangan dengan agama dan agama mengajarkan kita untuk tidak membuang sampah sembarangan sebab jika tak ada sampah dilingkungan kita maka itu artinya lingkungan tersebut bersih dan dalam agama sudah menjelaskan bahwa " kebersihan merupakan sebagian dari pada iman"

Selain itu juga pengamatan dilakukan awal tahun 2016 terdapat anak yang belum terbiasa dalam mengucapkan do'a sesudah makan, padahal do'a sesudah makan merupakan do'a pendek yang sering diucapakan di dalam kelas. Pada dasarnya mengucapkan doa pendek menurut Badan Nasional Standar Pendidikan yang sering disingkat dengan BNSP merupakan bagian dari kegiatan yang harus dibiasakan pada anak usia dini.

Dari beberapa pengamatan diatas maka peneliti mencoba melakukan penelitian tentang strategi pengembangan kegiatan keagamaan di TK Harapan Ibu Tanah Mas Banyuasin.

Dan berkaitan dengan hasil wawancara pada kepala sekolah di TK Harapan Ibu Tanah Mas tentang visi dan misi TK tersebut bahwa visi TK Harapan Ibu adalah membentuk anak yang berkarakter, beriman dan takwa kepada Tuhan YME, cerdas, mandiri dan berwawasan lingkungan. Sedangkan misinya yaitu sebagai berikut: 1) Menyelenggarakan pendidikan yg berkualitas; 2) Meningkatkan kualitas tenaga kependidikan; 3) Mengembangkan dan melaksanakan pembelajaran berkarakter, PAKEM dan berwawasan lingkungan; dan 4) Meningkatkan kedisiplinan dalam pelaksanaan pembelajaran.

Pada tataran konsep atau teori TK Harapan Ibu Banyuasin memiliki tujuan pendidikan yang berkualitas, Untuk menciptakan generasi yang maju 


\section{Hasil Penelitian}

dalam hal ilmu pengetahuan serta berwawasan lingkungan bukanlah hal yang mudah untuk mewujudkannya tentunya ada kendala baik dari segi persaingan lembaga pendidikan dan segi usaha dalam meraih harapan yang sesuai dengan visi dan misi tersebut. Untuk mewujudkan visi juga misi tersebut tentulah para guru yang mengabdikan diri mereka di TK Harapan Ibu Tanah Mas Banyuasin memiiki berbagai macam strategi.

Dari uraian di atas maka dalam tesis ini akan meneliti tentang pengembangan nilai-nilai agama dan moral dimana pembahasan ini tentunya berkaitan dengan judul yang akan peneliti lakukan yakni strategi pengembangan kegiatan keagamaan anak usia dini di TK Harapan Ibu Tanah Mas. Dan ini artinya jika seorang guru sudah berusaha untuk menanam maka akan ada harapan untuk tumbuh dan strategi guru didalam menumbuhkan keagamaan pada anak merupakan hal yang perlu dilakukan oleh sang guru karena menumbuhkan itu artinya sama dengan mengembangkan dan mengembangkan merupakan kurikulum yang perlu diwujudkan agar upaya guru dalam mendidik anak bisa berhasil dengan optimal.

\section{Strategi Pengembangan kegiatan keagamaan AUD}

Secara etimologi strategi berasal dari kata benda dan kata kerja dalam bahasa yunani, sebagai kata benda, strategos merupakan gabungan kata stratos (militer) dan ago (memimpin/komandan), sebagai kata kerja, stratego, berarti merencanakan (Bahasa Inggrisnya strategy brarti a plan,method, or series of activities designed to achieves aparticular aducational goal) strategi dapat diartikan sebagai "siasat", "kiat", "trik" atau "cara". Secara terminologi strategi adalah rencana yang cermat mengenai kegiatan untuk mencapai sasaran khusus (Elhefni, 2011: 9).

Strategi diperlukan untuk memperluas arah dan tujuan. Strategi tersebut merupakan kebijakan mengimplementasikan program sebagai payung pada perumusan program dan kegiatan. Kata strategi berasal dari bahasa Yunani, yaitu stratogos atau strategis yang berarti jendral. Maksudnya disini adalah strategi seni para jendral. Maka dari sudut pandang militer strategi adalah cara menempatkan pasukan atau menyusun kekuatan tentara di medan perang agar musuh dapat dikalahkan (Amidah, 2015: 29).

Dari uraian di atas maka dapatlah dipahami bahwa pada dasarnya strategi merupakan cara yang dilakukan oleh suatu pihak dalam mencapai suatu tujuan tertentu dan tujuan tersebut haruslah jelas sehingga dalam meraihnya memerlukan upaya yang harus dilakukan oleh pihak yang bersangkutan. Dalam hal ini berkenaan dengan strategi dalam mengembangkan kegiatan keagamaan anak usia dini, maka disini tentunya sudah jelas bahwa tujuan yang akan diupayakan oleh seorang guru yakni mengembangkan kegiatan keagamaan anak usia dini. Dan hal inipun sesuai yang diungkapkan oleh Irawan yang menyatakan bahwa sesungguhnya strategi adalah " Cara atau taktik yang dipakai guru dalam kegiatan mengajar" (Irawan, 2001: 60).

"Pengembangan berasal dari kata dasar "kembang" mendapat awalan "Pe"dan akhiran "an". Artinya perbuatan yang menjadikan tambah sempurna (tentang pribadi, pikiran, dan pengetahuan)" (Depdikbud, 1994: 473). Dalam proses pengembangan disini strategi pihak sekolah sangatlah penting untuk diketahui dari segi usahanya dalam mengembangkan kegiatan keagamaan pada anak usia dini, maka dalam hal ini sangatlah perlu keandilan atau peran dari pihak sekolah khususnya guru maupun orang tua dalam mengusahakan tercapainya harapan yang diinginkan yakni harapan agar pengetahuan anak dalam kegiatan keagamaan bisa mereka peroleh dengan sebaik mungkin. Sehingga jika mereka memperoleh pengetahuan yang sudah direncanakan dalam menyampaikan kepada mereka maka dengan izin sang maha kuasa kepribadian anak akan terbentuk dengan baik juga karena anak akan mulai mampu memahami kebaikan dan sedikit demi sedikitpun akan melakukan kebaikan.

Jadi strategi pengembangan kegiatan keagamaan anak usia dini maksudnya dalam penelitian ini yaitu bagaiman cara-cara pihak sekolah dalam hal mengenalkan kegiatan keagamaan kepada peserta didik dengan harapan setelah mengenal akan hal itu anak akan mengerti sedikit demi sedikit tentang kegiatan keagamaan dan akan paham tentang kegiatan keagamaan juga akan melakukan kebaikan-kebaikan yang telah dikembangkan dalam kegiatan keagamaan tersebut. 


\section{Hasil Penelition}

\section{Strategi-strategi pengembangan kegiatan keagamaan anak usia dini.}

Strategi pengembangan kegiatan

keagamaan seperti apakah yang seharusnya dilakukan oleh pihak sekolah dalam mengembangkan kegiatan keagamaan. Dalam hal ini pengembangan kegiatan keagamaan yang disajikan dalam karya ilmiyah ini adalah pengembangan kegiatan keagamaan yang berupa pendidikan moral atau pendidikan akhlak dan bisa juga berupa pendidikan karakter. " T. Ramli dalam buku Agus Wibowo bahwa pendidikan Moral dan pendidikan akhlak memiliki esensi dan makna yang sama dengan pendidikan karakter " (Wibowo, 2013: 86). Maka dalam hal ini itu artinya strategi pendidikan karakter memiliki esensi makna yang sama juga dengan pengembangan kegiatan keagamaan anak usia dini.

Adapun strategi pengembangan kegiatan keagamaan yang peneliti maksud dalam penelitian ini adalah bagaimana cara pihak TK didalam mengembangkan kegiatan keagamaan yang seharusnya dilakukan, adapun teori menurut $\mathrm{M}$. Najib dkk tentang Tujuan sasaran dan target yang akan dicapai harus jelas dan konkret serta melaksanakan pembiasaan dalam kehidupan seharihari (Najib, 2016: 91)

Tujuan sasaran dan target yang akan dicapai harus jelas dan konkret; 1) Pengembangan kegiatan keagamaan akan lebih efektif dan efesien jika dikerjakan tidak hanya oleh sekolah; 2) Menyadarkan pada semua guru akan peran penting dan tanggung jawab dalam keberhasilan melaksanakan dan mencapai tujuan pengembangan kegiatan keagamaan pada peserta didik; 3) Melaksanakan pembiasaan dalam kehidupan seharihari.

Dari uraian di atas maka akan dijabarkan dalam penjelasannya dibawah ini, dimana dari keempat strategi itu merupakan hal-hal yang penting untuk diketahui oleh pihak sekolah atau oleh pendidik.

Maka dalam hal ini tujuan, sasaran dan target haruslah ditentukan, dan itu artinya perencanaan dan perumusan strategi pengembangan kegiatan keagamaan anak usia dini harus ditentukan tujuan, sasaran dan targetnya. Dimana menurut M. Najib dkk Perencanaan strategi disebut juga dengan perumusan strategi, Perencanaan strategi (strategic palnning) merupakan proses pemilihan tujuantujuan organisasi, penentuan strategi, kebijakan dan program-program strategi yang diperlukan untuk tujuan-tujuan tersebut dan menetapkan metodemetode yang diperlukan untuk menjamin bahwa strategi dan kebijakan telah diimplementasikan. Secara ringkas, perencanaan strategi merupakan proses perencanaan jangka panjang yang disusun dan digunakan untuk menentukan dan mencapai tujuan-tujuan organisasi (Najib, 2013: 91).

Ada tiga alasan yang menunjukkan arti penting perencanaan strategi bagi suatu organisasi, antara lain: 1) perencanaan strategi memberikan kerangka dasar dimana setiap bentuk bentuk perencanaan lainnya harus diambil; 2) Pemahaman terhadap perencanaan strategi akan mempermudah pemahaman berbagai bentuk perencanaan lainnya; dan 3) Perencanaan strategi sering menjadi titik permulaan bagi pemahaman dan penilaian kegiatankegiatan manajer dan organisasi (Handoko, 2001: 92).

Edward Sallis mengungkapkan bahwa perencanaan strategi memungkinkan formulasi prioritas jangka panjang dan perubahan organisasi berdasarkan pertimbangan rasional. Tanpa strategi, suatu organisasi tidak akan bisa yakin bagaimana ia bisa memanfaatkan berbagai kekuatan dan kesempatan yang dimilikinya (Amidah, 2015: 29).

Dan dari uraian di atas maka dapatlah dipahami bahwa perencanaan strategi pengembangan kegiatan keagamaan anak usia dini harus direncanakan dengan sebaik mungkin agar kegiatan keagamaan anak usia dini dapat dilakukan dengan terarah dan tidak menyimpang dari rencana strategi pengembangan kegiatan keagamaan anak usia dini yang sudah ditentukan berdasarkan hasil dari keputusan akan tujuan, sasaran dan target pengembangan kegiatan keagamaan anak usia dini. Dan kesemuanya itu harus jelas dan kongkret.

Tujuan yang akan disusun seperti dalam hal tingkat pencapaian pengembangan kegiatan keagamaan haruslah ada pedoman pihak sekolah terutama guru didalam mencapainya, seperti yang tertera dalam tabel dibawah ini yang merupakan tingkat pencapaian pengembangan nilai-nilai agama dan moral atau bisa disebut dengan pengembangan kegiatan keagamaan anak usia dini:

Mengenal agama yang dianut, Indikatornya: 1) Menyayikan lagu-lagu 


\section{Hasil Penelitian}

keagamaan yang sederhana; 2) Menyebutkan agama yang dianut; 3) Menyebutkan kitab agamanya; 4) Menyebutkan ciptaan-ciptaan Tuhan; 5) Menyebutkan rukun Islam dan rukun Iman; 6) Menyebutkan hari-hari besar agama; dan 7) Menyebutkan beberapa nama malaikat dan tugasnya.

Membiasakan diri beribadah, Indikatornya: 1) Melakukan shalat dhuha; 2) Mengucapkan surat al-Fatiha, al-ikhlas, al-Kafirun, al- Kautsar, An-Nass, Al-Asr, ayat kursi, AL-Falaq, Adduha, Al-Qurais; 3) Mengucapkan doa untuk kedua orang tua; 4) Mengucapkan doa selamat; 5) Mengucapkan doa selesai shalat; 6) Mengulang do'a sehari-hari; 7) Membaca huruf hijaiyyah; 80 Membaca iqro' 1 (satu); 9) Mengucapkan bacaanbacaan shalat; dan 10) Menirukan lafaz adzan dan iqomah.

Memahami perilaku mulia (jujur, penolong, sopan, hormat, dsb), Indikatornya: 1) Membedakan perilaku-perilaku misal: jujur - tidak jujur, sopan - tidak sopan, hormat- tidak hormat; 2) Terbiasa sopan dan hormat kepada teman dan orang lain; 3) Terbiasa membantu teman atau orang lain; 4) Terbiasa mengucapkan ma'af dan mema'afkan; dan 5) Terbiasa jujur.

Membedakan perilaku baik dan buruk, Indikatornya: 1) Menyebutkan contoh perilaku baik dan perilaku baru; 2) Memperagakan perilaku baik; dan 3) Menunjukkan perbuatan yang baik dan yang buruk.

Mengenal ritual dan hari besar agama, Indikatornya: 1) Menyebutkan ritual shalat, puasa, shalat tarawih, hari raya; 2) Menyebutkan hari-hari besar agama Islam; 3) Menyebutkan ritual hari besar agama Islam; dan 4) Mengikuti perayaan hari-hari besar agama Islam.

Menghormati agama orang lain, Indikatornya: 1) Terbiasa menghormati teman yang sedang beribadah; dan 2) menghormati perayaan agama lain (IGTK-PGRI, 2012: 1-2).

Dari keterangan di atas sesungguhnya ada persamaan dengan tingkat pencapaian kegiatan keagamaan pada anak usia dini yang telah ditetapkan oleh BNSP dimana dalam tabel yang tertera menurut Badan Nasional Standar Pendidikan yang sering disingkat dengan BNSP yakni sebagai berikut (Wiyani, tt: 179):

\begin{tabular}{|c|c|}
\hline Usia & Perkembangan Moral dan Agama \\
\hline $\begin{array}{l}2-3 \\
\text { tahun }\end{array}$ & $\begin{array}{llr}\text { - } & \text { Meniru } & \text { gerakan } \\
\text { berdoa/sembahyang } & \text { sesuai } \\
\text { dengan agamanya. } & \\
\text { - } & \begin{array}{l}\text { Hafal doa-doa pendek } \\
\text { dengan agamanya }\end{array} & \text { sesuai } \\
\text { - } & \text { Memahami } & \text { kapan } \\
\text { mengucapkan } & \text { salam, } \\
\text { terimakasih, maaf } & \text { dan } \\
\text { sebagainya } & \end{array}$ \\
\hline $\begin{array}{l}3-4 \\
\text { tahun }\end{array}$ & 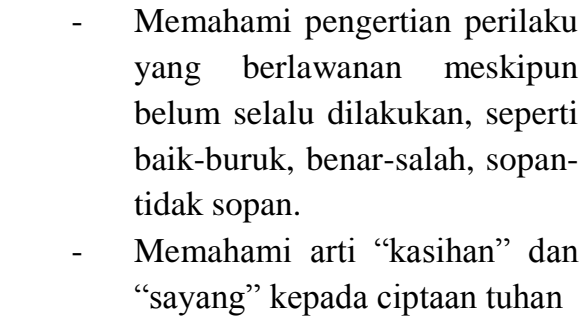 \\
\hline $\begin{array}{l}4-5 \\
\text { tahun }\end{array}$ & $\begin{array}{ll}\text { - } & \text { Mengenal tuhan melalui agama } \\
\text { yang dianutnya } \\
\text { - } \\
\text { - } \\
\text { Meniru gerakan ibadah } \\
\text { Mengucapkan doa sebelum } \\
\text { dan/atau sesudah melakukan } \\
\text { sesuau } \\
\text { Mengenal perilaku baik/sopan } \\
\text { dan buruk } \\
\text { Membiasakan diri berprilaku } \\
\text { baik } \\
\text { Mengucapkan salam dan } \\
\text { membalas salam }\end{array}$ \\
\hline $\begin{array}{l}5-6 \\
\text { tahun }\end{array}$ & $\begin{array}{ll}\text { - } & \text { Mengenal agama yang dianut } \\
\text { - } & \text { Membiasakan diri beribadah } \\
\text { - } & \text { Memahami perilaku mulia } \\
& \text { (jujur, penolong, sopan, hormat } \\
\text { dsb) } & \\
\text { - } & \text { Mengenal perilaku baik dan } \\
\text { buruk } \\
\text { - } \\
\text { Mengenal ritual dan hari besar } \\
\text { keagamaan } \\
\text { - Menghormati agama orang lain }\end{array}$ \\
\hline
\end{tabular}

Dari tabel di atas maka pada dasarnya pengenalan peraturan, pengenalan sopan santun, pengenalan baik dan buruk begitu juga pengenalan salah dan benar pada anak usia dini sesungguhnya dapat dikembangkan kepada mereka sesuai dengan umur mereka. Sebagai seorang pendidik perlulah mengetahui akan tingkat pencapaian pengembangan keagamaan anak usia dini, adapun aspek perkembangan anak dalam buku Isjoni yang 
berkenaan dengan pengembangan kegiatan keagamaan anak usia dini diantaranya ada beberapa komponen dari pengembangan tersebut yakni meliputi: 1) Mengenal aturan; 2) Mengenal sopan santun; 3) Salah dan benar; dan 4) Baik dan buruk (Isjoni, 2011: 112).

Dalam hal ini aspek moral tentunya berkaitan dengan pengembangan kegiatan keagamaan anak usia dini, dimana hal yang pertama yakni "mengenal aturan". Anak usia dini perlu mengetahui aturan-aturaan sebagai contoh aturan ketika hendak shalat haruslah berpakaian bersih dan harus pula berwudlu, atau aturan lainnya. Jika kembali pada tabel yang di atas yakni tabel tingkat pencapaian keagamaan menurut BNSP, maka kegiatan keagamaan yang pertama kali harus dicapai oleh anak usia dini adalah kemampuannya dalam menirukan gerakan sembahyang. Sembahyang dapat diartikan dengan beribadahnya seorang hamba kepada Tuhan sebagai Sang Pencipta alam semesta (Wiyani, tt: 179). Dan hal ini tentunya berkaitan dengan memperkenalkan aturan pada anak usia dini yakni aturan didalam beribadah.

Dan komponen yang kedua dalam perkembangan anak dari segi kegiatan pengembangan kegiatan keagamaann anak usia dini yakni mengenal "sopan santun", sudah menjadi harapan pendidik dan orang tua agar anak-anaknya memiliki sifat sopan dan santun, kemudian komponen yang ketiga yakni salah dan benar. Anak harus memilki pengetahuan tersebut karena tanpa bimbingan guru maka pengetahuan hal yang benar dan hal yang salah tidak diterima oleh anak dengan baik nantinya. Dan selanjutnya yang terakhir yaitu baik buruk, hal yang baik dan hal yang burukpun harus dikenalkan pada anak sedini mungkin agar anak memiliki kepribadian yang baik.

Maka dari pada itu hendaknya pihak sekolah memiliki strategi dalam menentukan tujuan, sasaran dan target demi mengembangkan kegiatan keagamaan anak usia dini, adapun tentunya dalam mewujudkan semua itu harus ada pedoman dan dasar dalam mengembangkan kegiatan tersebut dan memiliki strategi yang baik agar hasil pengembangan yang terealisasi juga baik.

Pengembangan kegiatan keagamaan akan lebih efektif dan efesien jika dikerjakan tidak hanya oleh sekolah.
Pengembangan kegiatan keagamaan akan lebih efektif dan efesien jika dikerjakan tidak hanya oleh sekolah, melainkan harus ada kerjasama antara sekolah dengan orang tua peserta didik. Ini artinya orang tua siswa merupakan elemen penting dalam melaksanakan keberhasilan pengembangan kegiatan keagamanan anak usia dini, pendidikan akan sulit berhasil tanpa dukungan dan dorongan dari orang tua, begitu pentingnya hubungan antara pihak TK dalam meningkatkan komunikasi dengan orang tua siswa dengan harapan dengan adanya kerjasama yang baik antara keduanya akan meningkatkan perkembangan anak khususnya dalam mengembangkan kegiatan keagamaan anak usia dini.

Sekolah perlu bekerjasama secara sinergis dengan keluarga agar sekolah bisa melakukan perubahan pada diri orang tua sebagai syarat berhasilnya pendidikan karakter bagi anak (Najib, 2016: 90).

Menyadarkan pada semua guru akan peran penting dan tanggung jawab dalam keberhasilan melaksanakan dan mencapai tujuan pengembangan kegiatan keagamaan pada peserta didik.

Strategi selanjutnya yaitu menyadarkan semua guru akan peran penting dan tanggung jawab dalam keberhasilan dan pencapaian tujuan pengembangan kegiatan keagamaan anak usia dini, itulah sebabnya guru harus benar-benar memahami filosofi seorang guru, tidak sekedar teknis melaksanakan pembelajaran. Pembelajaran yang dilaksanakan oleh guru harus mengembangkan kesadaran akan pentingnya keterpaduan hati, pikiran, tangan, cipta, rasa dan karsa dikalangan peserta didik guna mengembangkan karakter masing-masing. Keterpaduan ini penting artinya agar para peserta didik bisa memahami kebaikan, mencintai kebaikan, dan melakukan kebaikan.

Dalam hal ini pengembangan kegiatan keagamaan akan bisa berhasil jika pihak sekolah mampu menyadarkan para guru untuk bisa terus memberikan pengertian pada anak bahwa pengembangan kegiatan keagamaan anak usia dini itu penting dan akan mengantarkan anak menjadi anak sholeh dan sholehah juga berbakti pada orang tua dan guru. Dan peran guru untuk terus memberikan motivasi pada anak arus terus 


\section{Haril Penelitian}

terealisasi khususnya ketika dalam pembelajaran akan dimulai maupun akan diakhiri. Karena menurut asumsi yang ada anak murid itu lebih menurut pada guru dari pada orang tuanya, oleh sebab itu pihak sekolah hendaknya terus meningkatkan SDM guru agar guru semakin menyadari betapa sangat pentingnya peran guru dalam melaksanakan tujuan yang akan dilaksanakan, dan hal ini bisa dilakukan dengan mengikut sertakan guru dalam seminar-seminar atau pelatihan-pelatihan.

\section{Melaksanakan pembiasaan dalam kehidupan sehari-hari}

Pengembangan kegiatan keagamaan anak usia dini perlulah dibiasakan dalam penerapannya. Dan pendidikan karakter dalam hal mengembangkan kegiatan keagamaan adalah merupakan proses pembiasaan dalam kehidupan sehari-hari, khususnya disekolah yang dapat dimonitor dan dikontrol oleh kepala sekolah dan guru. Diharapkan orang tua peserta didik juga memonitor dan mengontrol perilaku sehari-hari peserta didik dilingkungan keluarga dan masyarakat.

Membangun karakter, akhlak, moral atau dalam hal karya ilmiyah ini disebut dengan mengembangkan kegiatan keagamaan pada anak maka hendaknya menjadikan mereka terbiasa untuk berperilaku baik. Jika anak sudah terbiasa melakukan kebiasaan baik, maka ketika mereka tidak melakukan kebiasaan itu akan timbul perasaan bersalah, dan tentu saja tidak akan mengulangi kelalaian itu. Sebagai contoh, seorang anak yang terbiasa makan tiga kali sehari, akan merasa tidak enak bila makan hanya dua kali sehari. Dengan demikian, kebiasaan baik yang sudah menjadi instink, otomatis akan membuat anak merasa kurang nyaman bila tidak melakukan kebiasaan baik tersebut (Wibowo, tt: 86).

Strategi pembiasaan dinilai sangat efektif jika diterapkan terhadap anak usia dini. Karena anak usia dini mudah merekam apa yang mereka lihat, apa yang orang dewasa lakukan, dan apa yang diajarkan oleh orang tuanya maupun gurunya. Maka dari itu anak usia dini perlu bimbingan dalam melakukan rutinitas mereka sehari-hari, dari rutinitas itupun hendaknya memiliki pondasi yang kuat dalam pengembangannya, khususnya dalam pengembangan keagamaan anak. dan pondasi yang kuat tersebut yang berlandaskan al-Qur'an dan hadist tentunya.

Temuan dalam penelitian tentang strategi pengembangan kegiatan keagamaan anak usia dini di TK Harapan Ibu Tanah Mas Banyuasain yaitu: Merumusan tujuan sasaran dan target yang akan dicapai dalam mengembangkan kegiatan keagamaan anak usia dini. Menyusun programprogram pembiasaan dalam kegiatan pengembangan keagamaan anak usia dini, Menerapkan pengembangan kegiatan keagamaan anak usia dini, Menyadarkan guru akan peran penting dan tanggung jawab dalam keberhasilan melaksanakan dan mencapai tujuan pembelajaran baik itu pengembangan kegiatan keagamaan atau pengembangan yang lain pada peserta didik, ini dilakukan oleh kepala sekolah dengan cara mengikut sertakan para guru dalam kegiatan seminar-seminar, pelatihan-pelatihan atau yang lainnya demi meningkatkan SDM guru tersebut.

Selanjutnya pihak sekolah bekerja sama dengan wali atau orang tua siswa melalui kegiatan "arisan rutin bulanan" sebagai wahana untuk sharing baik dari pihak sekolah mengenai masalahmasalah sekolah kepada wali murid ataupun sebaliknya. Sebagai strategi mengajak wali murid untuk lebih memiliki perhatian kepada anakanaknya demi mengembangkan kegiatan keagamaan anak.

Dan temuan yang kedua yakni Metode pembelajaran dalam mengembangkan kegiatan keagamaan anak usia dini di TK Harapan Ibu Tanah Mas Banyuasin yaitu dengan menggunakan metode keteladanan, metode pembiasaan, metode nasehat, metode hadiah dan hukuman, metode perhatian dan pengawasan, metode cerita, dan metode permainan.

Kemudian temuan yang ketiga, Faktor pendukung dan penghambat dalam mengembangkan kegiatan keagamaan anak usia dini di TK Harapan Ibu Tanah Mas Banyuasin, adapun faktor pendukungnya adalah adanya kesadaran dari guru kelas akan hal pentingnya pengembangan kegiatan keagamaan anak usia dini, adanya sarana dan prasarana yang baik, terjalinnya kerja sama yang harmonis antara pihak sekolah dan orang tua dalam hal mengembangkan kegiatan keagamaan anak usia dini, adanya perhatian baik dari guru dan orang tua, adanya kesemangatan dari 


\section{Haril Penelitian}

peserta didik adapun penghambat dalam mengembangkan kegiatan keagamaan anak usia dini yaitu tidak adanya kesadaran dari guru akan hal penting pengembangan kegiatan keagamaan, kurangnya sarana dan prasarana, tidak terjalinnya kerjasama yang baik antara orang tua dan guru, kurangnya perhatian orang tua dan guru dalam hal kegiatan keagamaan anak usia dini dan terakhir tidak adanya kesemangatan dari peserta didik didalam mengikuti kegiatan keagamaan yang berlangsung.

\section{Kesimpulan}

Berdasarkan deskripsi analisis data yang telah diperoleh maka dapat disimpulkan bahwa pengembangan kegiatan keagamaan anak usia dini di TK Harapan Ibu Tanah Mas Banyuasain yaitu: pertama, strategi pihak TK dalam mengembangkan kegiatan keagamaan anak usia dini di TK Harapan Ibu Tanah Banyuasin ditempuh dengan menetapkan pengembangan kegiatan keagamaan AUD yang hendak diinternalisasikan, menetapkan bentuk penilaiannya, merencanakan pembiasaan sehari-hari beserta program-program kegiatan keagamaannya, menerapkan pengembangan kegiatan keagamaannya, menyadarkan pada semua guru akan peran penting dan tanggung jawab dalam keberhasilan mencapai tujuan pengembangan kegiatan keagamaan pada anak usia dini, serta melakukan kerja sama dengan wali siswa dalam hal pengembangan kegiatan keagamaan anak usia dini di TK tersebut. Lalu penemuan yang kedua, menemukan metode pembelajaran yang dipakai yakni menggunakan metode keteladanan, pembiasaan, perhatian dan pengawasan, metode nasehat, metode permainan dan metode cerita.

Kemudian temuan yang ketiga, Faktor pendukung dalam mengembangkan kegiatan keagamaan anak usia dini di TK Harapan Ibu Tanah Mas Banyuasin adalah adanya kesadaran dari guru kelas akan hal pentingnya pengembangan kegiatan keagamaan anak usia dini, adanya sarana dan prasarana yang baik, terjalinnya kerja sama yang harmonis antara pihak sekolah dan orang tua dalam hal mengembangkan kegiatan keagamaan anak usia dini, adanya perhatian baik dari guru dan orang tua, adanya kesemangatan dari peserta didik adapun penghambat dalam mengembangkan kegiatan keagamaan anak usia dini yaitu tidak adanya kesadaran dari guru akan hal penting pengembangan kegiatan keagamaan, kurangnya sarana dan prasarana, tidak terjalinnya kerjasama yang baik antara orang tua dan guru, kurangnya perhatian orang tua dan guru dalam hal kegiatan keagamaan anak usia dini dan terakhir tidak adanya kesemangatan dari peserta didik didalam mengikuti kegiatan keagamaan yang berlangsung.

\section{Daftar Pustaka}

Abrurrahman, Mulyono. Pendidikan Bagi Anak Berkesulitan belajar. Jakarta: Rineka Cipta. 2003.

Ahmad, Nurwadjah. Tafsir Ayat-Ayat Pendidikan: Hati yang Selamat Hingga Kisah Luqman. Bandung: Marja. 2007.

Arikunto, Suharsimi. Prosedur Penelitian Suatu Pendekatan Praktek, Jakarta: Rineka Cipta. 2002.

Amidah. (Tesis) Strategi guru dalam proses pembelajaran untuk peningkatan minat belajar siswa pada mata pelajaran pendidikan agama islam disekolah dasar negeri 147 palembang. Palembang: UIN Raden Fatah. 2015.

Ardy, Novan, Wiyani. Psikologi Perkembangan anak usia dini. Yogyakarta: Penerbit Gava Media. 2014.

Binti Maunah. Metodelogi Pengajaran Agama Islam. Yogyakarta:Teras. 2014.

B. Harlock, Elizabeth. perkembangan anak. Jakarta: Penerbit Erlangga. 1979.

Drajat, Zakiah. Ilmu jiwa agama. Jakarta: Bulan Bintang. 2005.

Depdikbud. kamus basar bahasa Indonesia. Jakarta: Balai Pustaka. 1994.

Depdiknas(a). Undang-Undang Nomor 20 Tahun 2003 Tentang Sisdiknas. Jakarta: CV.Eka Jaya. 2003.

Elhefni., dkk. Strategi Pembelajaran. Palembang: CV. Elegance Quality. 2011.

Emzir. Metodologi Penelitian Kualitatif Analisis Data. Jakarta: PT Raja Grafindo Persada. 2010.

Fadlillah, Muhammad. Desain Pembelajaran PAUD. Yogyakarta: Ar-Ruzz. 2012.

Handoko, T. Hani. Manajemen. Yogyakarta: PBFE. 2001. 


\section{Hasil Penelitian}

H. Idris, Meity. Strategi Pembelajaran yang Menyenangkan. Jakarta: PT.Luxima Metro Media. 2015 Strategi pengembangan kegiatan keagamaan anak usia dini di TK Harapan Ibu Tanah Mas Banyuasin

Idi, Abdullah. Sosiologi Pendidikan individu, masyarakat dan pendidikan. Jakarta: PT. Rajagrafindo persada. 2013.

Isjoni. Model pembelajaran anak usia dini. Bandung: Penerbit Alfabeta. 2011.

Jalaludin. Psikologi Agama. Jakarta: Raja Grafindo Persada. 1997.

Kurniasih, Imas. Pendidikan Anak Usia Dini. Edukasi. 2011.

Mulyasa. Manajemen PAUD. Bandung: PT Remaja Rosdakarya Offset. 2014.

Muslim, Imam. Shahih Muslim, Juz II. Surabaya: Syarikat 'Alawi.

Najib, Muhammad., dkk. Manajemen strategic pendidikan karakterbagi anak usia dini. Yogyakarta : penerbit gava media. 2016.

Nasution., S. Metode Reseach (Penelitian Ilmiah). Jakarta : Bumi Aksara. 2005.

Paguyuban TK Pembina Sumatera Selatan dan IGTK- PGRI Sumatera-Selatan. Program pembelajaran PAUD kelompok usia 5-6. Palembang. 2012.

Prasetya, Irawan., dkk. Teori Belajar, Motivasi, dan keterampilan mengajar. Jakarta : Depdikbud. 2001.

Rosyadi, Khairon. Pendidikan Propetik. Yogyakarta : Pustaka Pelajar. 2009.

Sugiyono. Metodologi Penelitian Pendekatan Kualitatif, Kuantitatif Dan $R \quad \& D$. Bandung: Alfabeta. 2015.

Sujiono, Yuliani Nurani. Konsep Dasar Pendidikan anak usia dini. Jakarta: PT Indeks Permata Puri Media. 2012.

Sukardi, Ismail. Model-model pembelajaran Modern, (Palembang : Tunas Gemilang Press. 2013.

Sururin. Ilmu Jiwa Agama. Jakarta: Raja Grafindo Persada. 2004.

Undang-undang Republik Indonesia Nomor 20 Tahun 2003 tentang sistem pendidikan Nasional pasal 3

Wibowo, Agus. Pendidikan Karakter usia dini. Yogyakarta: Pustaka Palajar. 2013. 